\title{
AC 2010-280: SPAIN'S MASTER OF LEADERSHIP IN CIVIL ENGINEERING: CASE STUDY
}

\section{Stuart Walesh, S. G. Walesh Consulting}

S. Walesh is an independent consultant in the U.S. with previous experience in the private, government, and academic sectors.

Javier Conde, National University of Distance Education

J. Conde is Professor of Management at the National University of Distance Education in Madrid, Spain.

Jose M. de Urena, University of Castilla-La Mancha

J. M. de Urena is Professor of Urban \& Regional Planning at the University of Castilla-La Mancha in Ciudad Real, Spain

Jose Turmo, University of Castilla-La Mancha

J. Turmo is Professor of Structural Design at the University of Castilla-La Mancha in Ciudad Real, Spain.

Raul Vizcaino, University of Castilla-La Mancha 


\title{
Spain's Master of Leadership in Civil Engineering: Case Study
}

\begin{abstract}
The paper suggests the value of developing a civil engineering graduate program focused on management, leadership, and innovation. Described are the creation and operation of a Master of Leadership in Civil Engineering (MLCE) program in Spain supported by a private foundation, organized by one of Spain's youngest civil engineering schools, and involving collaboration with the nation's other nine civil engineering schools.
\end{abstract}

The paper describes the motivation and inspiration for the master's program and outlines the entrepreneurial effort required to create it. Personal contacts were helpful as was establishing the program within a young, dynamic, and developing school and drawing on knowledge of potential sources of external financial support. The paper discusses how the scheduling and scope of the program complement Spain's five-year baccalaureate civil engineering degree.

The paper explains how 20 students are admitted to the program by selectively drawing on Spain's 10 civil engineering schools. The paper also outlines the curricula and describes the selection and role of a faculty composed of a mixture of leading Spanish and foreign academics, practitioners, and specialists in management, leadership, and innovation.

The paper includes an evaluation of the program and a discussion of the potential usefulness of applying all or portions of it in other environments, including other countries. Various aspects of Spain's unique Master of Leadership in Civil Engineering may interest U.S. civil engineering educators who are pondering ways to tailor elements of the Civil Engineering Body of Knowledge (BOK) to their programs. Spain's effort may also be of interest to educators in other nations who are improving their programs. Possibly applicable elements of the Spanish master's program include adopting a management-leadership-innovation theme, using some of the content, incorporating an internship, selecting top students from within a system of universities, and assembling a heterogeneous faculty.

Keywords - BOK, civil engineering, consortium, curriculum, faculty, industry, innovation, internship, leadership, management, master's degree, project, Spain

\section{Introduction}

Spain's five-year civil engineering programs devote very little time to group and personal management and leadership behaviour. That, and innovation, are increasingly relevant in enterprise development and in civil engineering. Accordingly, a Master of Leadership in Civil Engineering (MLCE) program was developed. Supported by a private foundation, the master's degree program was organized and is operated by and at one of Spain's youngest civil engineering schools and involves collaboration with the country's other nine civil engineering schools. The purpose of this paper is to share ideas and information about the master's program that might be of value to engineering educators in other countries, especially U.S. educators who 
are pondering ways to reflect the Civil Engineering Body of Knowledge (BOK) in their undergraduate and graduate programs.

Leadership, as used in the title of this paper, is shorthand for what are usually referred to as leadership and management. Leading means influencing the process of deciding where an organization should go or what it should do. In contrast, and in a complementary manner, managing concentrates on how the organization will go where it decides to go or do what it wants to do. Leading focuses on "what" and managing stresses "how." Leading has to do with direction and managing with process or, as stated by author Steven Covey, "management is about doing things right and leadership is about doing the right things." 1

\section{Undergraduate Engineering Education in Spain}

Before 2010, there were two types of civil engineering undergraduate programs that students followed, a three year Technical Public Works Engineer and a five year Superior Civil Engineer. Ten Schools in Spain grant the degree of Superior Civil Engineer. Beginning in 2010, the Bologna agreement changes engineering studies to a progressive undergraduate degree and a graduate degree approach.

The five year studies in civil engineering are composed mainly of technical aspects with very little attention given to socio-economic, organizational, or managerial components. The studies are roughly composed of an equivalent of two years basic sciences (mathematics, physics, geometry, drawing, geology, mechanics, and statistics), two years of professional subjects (structures, soil mechanics, applied hydraulics, transportation, building procedures, and physical planning), and one year of optional subjects. Within this framework students are confronted with one subject of micro and macro economics and another of management, representing approximately four percent of a student's total work load. Civil engineering in Spain is considered one of the most difficult, challenging, and demanding engineering studies and, therefore, attracts some rather brilliant students.

The school of the University of Castilla La Mancha follows this framework although, because it incorporates project/problem based learning, it indirectly facilitates and requires that the students "learn" some additional aspects of management such as team work, conflict resolution, and communication of ideas. See Appendix A for a summary of the five-year University of CastillaLa Mancha Civil Engineering curriculum.

\section{History of the Master's Degree Program}

In 1998, The School of Civil Engineering was created at the University of Castilla LaMancha in the city of Ciudad Real, Spain. The school was established with a high quality project/problembased learning approach and, relative to Spanish standards, a reduced number of students, (only 50 students were accepted for the five-year degree in Civil Engineering). Three years after its creation the school was selected as one of best in the country by the El Mundo, the Spanish 
newspaper. In 2000, two years after its creation, the School of Civil Engineering started a graduate program titled the Spatial Implications of Civil Engineering.

The Rafael del Pino Foundation (FRDP) ${ }^{2}$ was established in Spain in 1999 with a considerable personal financial contribution by its founder, civil engineer Rafael del Pino. The foundation is Spain's private foundation with the biggest financial allocation. Rafael del Pino established the building company, Ferrovial, in the late 1940's. He was its principal shareholder and, during his presidency, Ferrovial developed into one of Spain's five largest building companies and the Ferrovial group grew into a multinational conglomerate of companies diversified into the utilities and managing of facilities such as toll roads, airports, and parking structures. Today, the Ferrovial Group has interests in many countries, including the U.S., and is the worlds' leading toll road managing company.

Rafael del Pino created the Foundation to promote "leadership" in Spain recognizing that his country had evolved considerably during the second half of the 20th century after a period that lacked political freedom. The country urgently needed leaders in various sectors and leadership and innovation were crucial for the future.

During the 2002-2003 academic year, the first class of the Spanish Civil Engineering Degree (five-years duration) was to graduate. Accordingly, the school sought an accomplished civil engineer to deliver the graduation lecture. An existing indirect personal contact between the founder dean of the School of Civil Engineering (one of the authors of the paper) and Mr. Rafael del Pino facilitated Mr. del Pino being chosen to deliver the gradation lecture. This contact led to a decision by the University of Castilla La Mancha to honor Mr. Rafael del Pino with a Doctor Honoris Causa Degree.

The graduation ceremony of the first class was combined with the Honorary Doctorate ceremony. And, after a few other activities, the Dean's School of Civil Engineering team and FRDP Director, Professor Amadeo Petitbò, suggested that the de Rafael del Pino Foundation finance the MLCE program. The program had two initial purposes: complement civil engineering education and enable the new school to offer something prestigious in which all the country's civil engineering schools would want to participate.

Civil engineering education would be complemented by offering a select and small group of recently-graduated civil engineers a short, intensive program so that they would be better able to start a path towards functioning as managers, directors, organizers, or executives in any civil engineering firm or government sector.

There were two possible clients of the MLCE program. The first was those recent graduates who had already shown some leadership and innovation knowledge, skills, and attitudes during their studies and the second was those civil engineering professionals that, after a few years' work, had demonstrated initial capabilities of becoming leaders. The final decision was to orient the program to recent graduates and selection was done among last year students. Accordingly, the initial program was oriented towards presenting a new professional perspective pointing out new areas of interest to persons who did not have specific experience. This was an "opening" approach rather than a "systematic and overall" one. 
Because of the second purpose, the new school offered something relevant to all the other schools of the country and that something would not be considered threatening to their areas of excellence. The fact that civil engineering schools have traditionally specialized in different technical aspects, rather than in management-leadership-innovation, meant that a graduate program in leadership was considered by the other schools as something that the new school could offer without threatening each school's excellence areas.

The MLCE program was directed to recent graduates and selection done through last year students in each school because this would be a marketing means to disseminate information about the new school to all the other schools of the country. The selection process was accomplished with the help of each school deans' office and the program was offered to a small group of students of each school. Since the program costs are supported 80 percent by the Rafael del Pino Foundation and 10 percent by the University of Castilla La Mancha, the students only pay for 10 percent of the actual marginal cost of the program, while most other master's programs are self-financed by fees.

The MLCE program is offered to students as a privilege and involves searching for and selecting students rather than waiting for them to apply. Given the special nature of the program, including its national scope and management-leadership-innovation theme, each school values participation in the program and the benefits provided to the students they select. All ten private and public schools of civil engineering of the country are collaborating in the selection process.

\section{Curriculum, Internship, Project, and Faculty}

\section{Overview}

The four-month (September through December) MLCE program, with students living in the same special residence, is appropriate in the Spanish context including the time frame within which graduates typically begin their professional work. Spanish students typically complete their five year baccalaureate program in June or July and usually begin their professional work in September. Therefore, participation in the MLCE program delays entry into employment by only four months.

The program has three major components which occur during the four month September through December period. The first is two months of lecturing and student academic work at the University of Castilla-La Mancha in Ciudad Real, about 100 miles south of Madrid, Spain's capital. The second is a one month internship in an enterprise during which the students are in close contact with one or more of the organization's leaders. The final component, which lasts three weeks and takes place back at the university, is preparation and presentation of a final dissertation.

Although both are graduate programs, the MLCE program and U.S. master's programs are very different. One is not intended to be like the other when compared on the basis of factors such as the academic background of the students and the purpose, content, and duration of the programs. 
For example, U.S. engineering master's degree programs are typically classroom-intensive while the MLCE program combines classroom experience with an internship and a project. Because of the differences between the two types of programs, sponsors of each type may be able to learn about and benefit from knowledge about both types of programs.

\section{Curriculum}

Lectures take place during September and October, on a Monday-to-Friday, morning-andafternoon basis. The main topics taught are integrated in the following modules with the numbers in parentheses indicating the approximate class hours devoted to the topics:

1) Organizational Behaviour (leadership and organizational behaviour, economic theory of leadership), (40);

2) Leadership Basis and Types of Leadership (leadership and types of leadership, how to improve leadership abilities), (40);

3) Grounds of Negotiation. Cooperation, Conflict and Negotiation (key strategies of negotiation, conflict resolution), (40);

4) Company Management in Civil Engineering (company management, project managing and leading, social responsibility in business), (40);

5) Strategic Company Management. Enterprises and Business Plan (strategic management of the company, entrepreneurs, business plan: company presentation card), (40);

6) Innovation Management and Technological Management in Civil Engineering. (innovation in civil engineering, innovation in project lay-out, innovation management), (20);

7) Process Reengineering (process reengineering, constant improvement systems, balanced scorecard), (20);

8) Communication and Emotional Intelligence (oral communication techniques, emotional intelligence, communication media: opportunity or threat), (40); and

9) Knowledge and Talent Management. Mentoring and Coaching (knowledge management, business communication and coaching, mentoring and coaching, talent administration), (20).

Appendix B is a detailed, small portion of the curriculum provided to illustrate additional detail. Books from which reading assignments are drawn during the MLCE program are listed in Appendix C.

These topics are taught by different means, depending on the subject and on the faculty. All sessions are both theoretical and practical and are directed by engineers in practice and professors from academia. Methods such case studies, group dynamics, debate groups, brainstorming, and open discussion are used. In addition, leaders from various companies and public sector organizations share their experiences with the students, communicate their own vision of leadership, and discuss them in an open environment. 
The lecturing period concludes at the end of October with students visiting, during one week, three engineering firms, a construction company, a consulting company, and an industrial company. With the help of their CEOs and leaders, the students have the opportunity to observe the best practices and relate them to the topics taught in the previous weeks. These visits help students get ready for the internship.

\section{Internship}

The internship occurs during November. The aim is that, for one month, the students study leadership styles present in a company, the organization's strategic plan, change management, communication policy, and negotiation with stakeholders. They do this with the help of their mentors. Each student shadows his or her mentor accompanying them to meetings or travels and having access to all the information about the company that the mentor can share.

Companies involved in this part of the program are presented to the students by employees who travel to Ciudad Real in the previous months. During these short visits, an outline of the firm is presented, different posts are offered to the students, and candidates are interviewed by the Human Resources Department of the firms. Final assignment of the internship is made by a mix of student and enterprise preferences.

Firms selected belong to consultancy, construction, or transportation areas. Some industrial companies, whose leadership programs are usually more developed, are also selected. Selection is made taking into account the excellence of the companies and the stays offered. Firms usually offer a small wage to cover accommodation and food. As stay is too short for the students to develop any work fruitful for the firm, the company's main interest is to recruit brilliant students for the future. Usually, a work offer follows the end of the internship.

During this internship, students can experience and apply the theoretical content they have learned in the previous months, such as organizational behaviour, types of leadership, conflict resolution, and negotiation.

\section{Project}

During the first three weeks of December, each student conducts a project and writes a paper to be defended at the end of December. The typical length of the papers ranges from 100 to 150 pages. Students are asked to carefully analyze any aspect of their internship relevant to the topics taught in the course and propose any innovation or improvement of any aspect of the company. The project is open and original and its content is a student's choice. Originality is taken into account in the final score. Examples of topics chosen are analysis of the leadership styles of mentors and modifying the strategies of the companies. Results of such analyses are usually sent to the companies. 


\section{Faculty}

Faculty are selected from among university professors and engineers or consultants in private practice. Selection is made according to their $\mathrm{CV}$, their professional and academic experience, and their leadership capabilities. Faculty for the 2009 edition of the MLCE program came from Holland, Spain, Switzerland, and the U.S. and were drawn from various professions namely civil engineering, economics, journalism, law, mechanical engineering, philosophy, and psychology. Faculty are recognized experts in the topics they teach. In addition to this, CEOs from Spanish organizations are selected as leaders to share their experience with the students. Evaluation of the students is taken into account for the selection of the faculty for the coming years. Every year, around fifteen people are teaching in the program and around six leaders are invited to share their expertise. Appendix D lists faculty and leaders who participated in the 2009 edition of the MLCE program.

\section{Student Selection Process}

\section{Overview}

Each year, 20 students are admitted to the MLCE program by selectively drawing on Spain's ten civil engineering schools. The process includes a pre-selection undertaken by each school which identifies approximately the top ten percent of each school's graduates. Pre-selection is followed by a CV review and foreign language and psychological tests undertaken by the University of Castilla La Mancha. The final 20 students are selected on the basis of their academic records, their previous experience in leadership and/or extracurricular activities, their attitude, and their knowledge of English.

\section{Details}

Each one of the nine Spanish public universities that have a School of Civil Engineering (Technical University of Madrid, University of Cantabria, Technical University of Valencia, Technical University of Cataluña, University of Granada, University of Coruña, University of Burgos, University of Alicante and University of Castilla-La Mancha) and the private one (University Alfonso X) selects a group of their best last year students by the beginning of the winter semester on the basis of their academic curriculum and their extra-academic attitudes and activities. Each one of these groups is briefed at their own school by one of the two directors of the MLCE program. General information about the program is also provided to each school in the form of posters and leaflets.

Interested students from within the select groups forward an application for the program to the program's office at the University of Castilla La Mancha. The application includes a letter of presentation, an academic certificate, and a CV. Each application must be specifically and formally supported by the student's dean which means that the candidate receives strong support from his or her school.

The selection process does not assure participation by a specific number of graduates from each school but tries to enroll between one and four students from each school. In some years, there 
are no students finally selected from any given school. At the same time the selection process is undertaken, students are also submitting other graduate study applications and/or participating in professional interviews. Experience indicates that between 10 and 15 percent of those accepted to the MLCE program decide not to enter it, in most cases because they find permanent employment.

Students are informed in early May if they are offered a place in the program and are given a couple of weeks to confirm their decision. Those who choose the program are given a short time to pay one third of their portion of the fees. Fees are around \$US 2,000 and represent about 10 percent of total costs of the program including tuition, lodging, meals, and transportation.

One of the strengths of the program is that students are lodged together in a separate small antique residence hall, as shown in Figure 1, used only for this purpose in an isolated situation about 10 kilometers (6 miles) from the city on a 600 hectare (1500 acre) agricultural and cattle breeding experimental property of the university. This living arrangement enhances learning and development of interpersonal relations among the program's students.

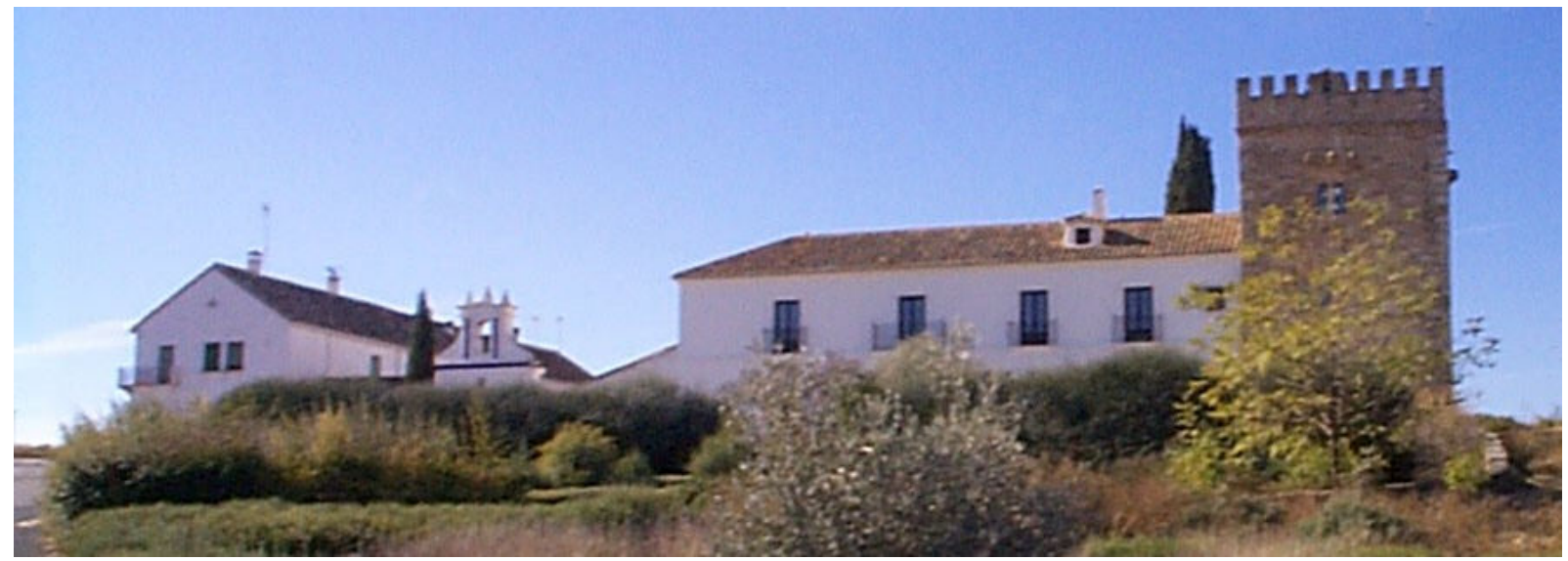

Figure. 1. Galiana - Student Residence Hall

\section{Evaluation}

The MLCE program professors evaluate students during the course and mentors evaluate their behaviour and initiative during the internship. Students present and defend their dissertation in front of a commission which scores their work. Based on this information and on their own interaction with the students, the directive commission of the program provides a global evaluation of the student.

Faculty are evaluated simultaneously once the lecture period is over, so all the faculty are evaluated on the same basis and students can compare their performance. This system has a drawback in that some of the teachers are evaluated two months after their lectures were given. So, in addition to this, students gather weekly with the academic director of the MLCE program 
to comment on the performance of the instructors and on the objective accomplishments. During these sessions, students propose improvements that are taken into account.

Students are asked to evaluate the performance of their teachers using the Likert scale. Questions cover topics such as objectives (stated course objectives were achieved/ course objectives were interesting); contents (course contents have been appealing, useful for the students' professional projection); methodology (teacher's explanations were clear and concise, classes have been interactive and entertaining, structured and organized, students were able to participate actively); resources ( notes, audiovisual resources provided in class were appropriate and sufficient); follow-up (amount of homework, usefulness of homework); professor attitude (adhesion to schedule, contact with the teacher). Marks obtained range from 5.0 to 8.5 over a possible range of ten, with an average of 7.0 for 2009 edition of the MLCE program.

Students were also queried about the organisation of the program. They were asked about the attitudes of the academic and administrative staff (promotion of spirit of leadership, keeping promises, involvement in building a bond of unity among the students); about the educational facilities (classroom, computer room, wifi); accommodation (facilities, staff); and boarding (food). Marks obtained range from 6.0 to 8.0, with an average of 7.0 for 2009 edition.

Students were also asked about themselves. Each student answered questions about their capabilities as a leader (self-confidence, emotional intelligence, communication skills), about their fellow class mates, and about their characteristics as a group member (generosity, sincerity, honesty, extroverted, rule keeper, industrious). As might be expected, these self appraisals were highly scattered.

Students were asked to evaluate their internship and the quality of their mentor as a leader. Likert scale questions about the internship included: How do you think the internship improved your vocational guidance?, how has your stay affected you in relation to your personal development (maturity, self-confidence, communication and teamwork)?, how do you feel about the expectations that you had created at the beginning of the program?, and to what extent are you satisfied with the guidance and direction received from your mentor and the tasks you were asked to perform? Specific questions about their mentors were varied ( knowledge of his or her area or discipline, capacity to negotiate in an effective way, ability to perform under pressure, ability to spot new opportunities, ability to coordinate activities, ability to use time effectively, ability to work in teams, ability to discover and use other people skills, ability to be understood).

CEOs who participate in the program, faculty, and mentors are questioned annually about the performance of the students. Their opinions indicate that the program is steadily improving from edition to edition. Excellence is recognized through the results of the evaluation and highlighting the participation and commitment level of the students. Internship mentors were thoroughly questioned about the behaviour and their perception of the skills of the students. They usually do not answer a questionnaire but give an overall impression of the student and a mark. Marks for the internship range from 6.7 to 7.9 of a possible 10 .

As another and long term means of program evaluation, an Alumni Association is to be founded with the help of the University of Castilla-La Mancha and the Rafael del Pino Foundation. This 
will facilitate a follow-up evaluation effort to determine the performance of the students once they graduate and enter practice.

Every October, a weekend gathering with former students is organized. The purpose of this is to transmit to the new students the results of the training and the benefit on their entrepreneurial life of the knowledge and experiences acquired during the program. From their experience, the directive commission of the MLCE program gathers ideas and information used to implement changes in and improvements to future editions of the program.

\section{Looking Forward}

Spain recognizes two types and lengths of undergraduate university studies, less so in the pure sciences and more so in the applied sciences. One type is the three year degree of a more applied character (e.g., nursing, teacher training, and technical engineering) and the other type is the five year degree of a more scientific character (e.g., medicine, civil engineering, humanities, law, and pure sciences). These are not sequential degrees but alternative ones. Accordingly, upon entering the university, a student must decide which of these two types of degrees he or she wishes to pursue. There are some connections between the two types of degrees, allowing students to transfer from one to the other.

Graduate studies in Spain were restricted to the doctorate up to the 1970's. Beginning then diverse master's degree studies were slowly established by various education and training entities in Spain. Some of these organizations were public and some private and some were created specifically to award master's degrees, an example being private business administration schools. As might be expected, some universities established master's degree programs having two year duration and others being much shorter.

The various master's degree programs were not formally recognized by the Spanish education laws until the 1980's. Accordingly, the country's master's studies were by then very diverse with respect to the sponsoring organization and the programs' structures and duration. The resulting diversity of structures, lengths, and sponsoring organizations resulted from the clear demand for this form of graduate studies and the lack of applicable federal legal regulations.

The 1984 New University Law introduced more flexibility and autonomy into the university system by establishing two types of degrees. One was the "nationally recognized" degrees, each of which had some prerequisites established by law. The other was "own university" degrees, which were mainly for graduate studies after the five-year university degrees. This law didn't clarify the master's degree framework and, therefore, many different entities collectively continued to offer master's degrees that were very diverse in scope and structure.

The Bologna agreement clarified the master's degree situation in Spain, by distinguishing between undergraduate degrees (three or four years) and graduate degrees (up to two years). Graduate degrees could be of two types. One is those pre-approved after an evaluation by a national body (ANECA, National Agency for Quality Assessment and Accreditation of Spain), granted by universities, and requiring a minimum length of one year of full time work (60 
credits). They are named University Masters, and most have national prerequisites and formal professional consequences. The second type of master's degree is outside of the preceding requirements. These can be granted by various education and training institution's similar to the past "own university" degree practice. In the long run, the University Masters will probably acquire a higher professional relevance.

Spanish universities are revising their education curricula. They must first decide if their "own university" degrees are to be continued or if they are to be transformed to the more demanding University Masters. One factor to consider is pros and cons of the length of their "own university" degrees in that some are much shorter than a year and others require one year. Another factor is revenue. Many of the institutions offering their "own university" master's degrees charge significant fees because they are self-financed. In contrast, fees for University Masters at public universities, which is where 90 percent of students study, will be set by regional governments which are responsible for Spain's public universities. These fees are expected to be smaller and entry requirements will be less specific. In this context, the University of Castilla La Mancha has to decide if the MLCE should be continued as an "own university" masters or if it should be transformed into a University Masters, that is the longer (up to two years) option.

Students in the fifth edition of the four month MLCE, which concluded in December 2009, value their participation. At the same time, many are willing to continue their graduate studies in the form of an extended program with a deeper and wider scope. They indicate that, before their participation in the MLCE, they were not conscious of the relevance of management, leadership, and innovation. Accordingly, they would now welcome more education and training in these areas.

The MLCE program organizers, that is, the University of Castilla LaMancha and the de Rafael del Pino Foundation, want to maintain contact with the program's graduates and facilitate group activities with them. This ongoing university-alumni contact is desired because of the increasing awareness within Spain's civil engineering profession of the MLCE program and its value to both graduates and employers. The university and the foundation are also increasingly aware of interest in creating leadership, management, and innovation in graduate programs for civil engineers with several or more years of experience. Perhaps, after an engineer has had some experience, the value of the program to them and their employer will be even higher.

Another factor being considered as the university and foundation look forward is the size of Ciudad Real, which is a small city. This creates challenges in attracting graduate students for a long period that is up to two years, given the difficulty of finding full or part-time employment.

Given the above considerations, the University of Castilla LaMancha will move forward with the following four actions:

1. Maintain an intensive four month MLCE program essentially like the present one, of course, with improvements resulting from the experience; use the same selection procedure with the other nine schools; obtain financing through the same private foundation; and restrict each class to about 20 students. 
2. Open up some of the content and activities within the MLCE program for a few undergraduate and graduate students of the other Civil Engineering programs of the University of Castilla La Mancha.

3. Establish a one or one and a half year University Master's Degree in Leadership and Business Administration in Civil Engineering, with more complete education and training in both areas, using a mixture of distance learning and short resident periods at the university. This program will be offered initially mainly to past graduates of the MLCE program, but not only with a minimum period of three years professional experience.

4. Open up some of these short resident period activities at the University of Castilla La Mancha to all the graduates of the MLCE initially and later on also of the University Master Degree in Leadership and Business Administration in Civil Engineering.

This strategy will respond to the wishes of students and organizers; provide a source of extra funds to finance the whole activities both by fees and by the extra funds the private foundation is ready to allocate; open up a path to integrate the activities with other activities at the School of Civil Engineering; and establish a combination of an intensive masters' program and a more complete one.

\section{Possible Applications in the U.S. and Elsewhere}

\section{Reform of U.S. Civil Engineering Education and Early Experience}

Recognizing the need for major change, U.S. civil engineering education and prelicensure experience are undergoing major reform. The effort is founded on a recently developed, welldefined body of knowledge (BOK) and recognition that fulfilling the BOK requires a bachelor's degree plus a master's degree, or approximately 30 semester credits, and experience. ${ }^{3}$

The reform effort, which has evolved and expanded over the past approximately 15 years, has borne fruit. Examples include ABET adoption of new civil engineering program criteria and new master's criteria. In addition, ABET removed the prohibition on accrediting programs at both the bachelor's and master's level. The American Society of Civil Engineers (ASCE) drafted a commentary which provides civil engineering program evaluators with guidelines for applying the new criteria and offers civil engineering faculty recommended measures to ensure full BOK implementation.

The reform effort captures the spirit of the U.S. National Academy of Engineering (NAE) which stated in its 2005 report ${ }^{4}$ : "The B.S. degree should be considered a pre-engineering or engineerin-training degree. Engineering programs should be accredited at both the B.S. and M.S. levels so that the M.S. degree can be recognized as the engineering professional degree." 
The reform effort is reflected in actions of the National Society of Professional Engineers (NSPE) and the National Council of Examiners of Engineering and Surveying (NCEES). For example, in 2002, NSPE adopted a policy ${ }^{5}$ which "supports the concept of engineering students meeting additional academic requirements as a prerequisite for licensure and practice of engineering at the professional level. Possible additional requirements include a master's degree or equivalent." NCEES modified the licensure Model Law to require that an engineer intern with a bachelor's degree must have "... an additional 30 [semester] credits of acceptable upper-level course work to be admitted to the PE examination.",

One of the most exciting results of the reform effort is that it has spawned many and varied discussions of civil engineering education and experience. The BOK has proven to be a forum where academics and practitioners can come together to discuss the specifics of preparing the U.S. civil engineer for the $21^{\text {st }}$ century. These fruitful conversations have also involved the U.S. accreditation and licensing communities may be influencing other U.S.-based engineering disciplines. For example, the American Academy of Environmental Engineers (AAEE) published a BOK report ${ }^{7}$ in 2009 . The chemical engineering profession driven in part by the recognition that, over the past 40 years, "the undergraduate curriculum in chemical engineering has remained nearly unchanged," conducted three workshops in 2003 that produced a vision and model for reform of undergraduate chemical engineering education ${ }^{8}$ and formed a BOK committee in 2009. The American Society of Mechanical Engineers (ASME) conducted a Global Summit on the Future of Mechanical Engineering in April 2008, ${ }^{9}$ the purpose of which was: "Articulate a global vision for the future of Mechanical Engineering." After the summit, ASME formed a Vision/Body of Knowledge Task Force.

As suggested by the preceding, many members of the U.S. civil engineering academic community are considering changes to their particular programs. Some of these contemplated changes are meant to satisfy the minimum expectations of the new accreditation criteria. Other changes are more broadly based and are driven by the realization that major program changeschanges that go way beyond the minimum requirements-are possible. Many U.S. civil engineering educators, within the framework of each institution's traditions, mission, and aspirations, are open to and are searching for new approaches to the curricular, co-curricular, and extra-curricular elements of their programs.

\section{Possible Relevance of the Spanish Master's Program in the U.S.}

Accordingly, various aspects of Spain's MLCE may interest some U.S. civil engineering educators who are pondering ways to implement the BOK as well as educators in other nation's who are improving their programs. Some possibilities follow:

1. Adopt the management-leadership-innovation theme of the MLCE program for a practice-oriented master's degree program.

The Civil Engineering BOK includes many outcomes that explicitly mention management, leadership, and innovation or are related to them. Examples of these outcomes, referred to by their numbers and short titles, are: 9. Design; 13. Project Management; 17. Public Policy; 18. Business and Public Administration; 20, Leadership; 21. Teamwork; and 22, Attitudes. All of these are to be introduced at the undergraduate 
level and taken to at least Bloom's Taxonomy comprehension level of cognitive achievement.

Equally important, in the context of this paper, is Outcome 15, Technical Specialization. The BOK Outcome Rubric appendix in the BOK report ${ }^{3}$ indicates that the Technical Specialization outcome is to be fulfilled primarily by the master's degree or equivalent. The report states: "Advanced technical specialization includes all traditionally defined areas of civil engineering practice, but also includes coherent combinations of these traditional areas - that is, advanced knowledge and skills in the area of general civil engineering are appropriate within the context of advanced specialization." This suggests that the Technical Specialization outcome could be fulfilled with a managementleadership-innovation oriented program. An example would be a Master's in Public Works Engineering.

2. Draw on some of the content of the MLCE program.

Because of its leadership focus, the MLCE classroom portion of the program includes a variety of topics such as organizational behaviour, negotiation, social responsibility in business, strategic planning, innovation, constant improvement systems, emotional intelligence, mentoring, and coaching. Even if a particular graduate program does not follow a leadership theme, some of these topics may be appropriate given their relevance to the practice of civil engineering. For example, innovation could be the theme of a technical master's program.

3. Incorporate an internship similar to the MLCE program.

As already noted, the Spanish program includes a one-month internship during which the master's candidates are closely linked with high-level managers and executives. Carrying this idea into U.S. civil engineering education, a one-year master's program might include a month or two summer internship and possibly a project during the summer immediately following the academic year. Or the master's program might begin with the spring semester, include a summer internship and possibly a project, and conclude with the fall semester of primarily classes and/or project work.

The internship could be with a private sector or government manager or executive. Such an internship would require the generous support of the manager or executive and their organization. However, the productive efforts of the intern, who by this time will have earned a bachelor's degree in civil engineering and be well into or have almost completed the master's degree program, might serve as at least partial compensation.

4. Select top students from within a consortium of institutions to participate in a common master's degree program at one institution.

Recall that the Spanish program draws "top" students from the nation's ten universities that offer civil engineering programs. Parallel possibilities in the U.S. include a state's 
system of universities or a consortium of similar institutions such as the 11- school Midwestern Undergraduate Private Engineering Colleges.

These very promising students could come to one campus, live in a residential setting, and participate in a common master's program. That program might feature a management-leadership-innovation theme, like the Spanish program, or possibly a more technically-oriented theme.

Assuming that a master's degree program with a management-leadership-innovation theme is unique, civil engineering departments within the consortium would probably be inclined to work together. This situation contrasts with trying to establish a more conventional master's program at one institution in an area, for example, structures, that is available at all or most of the institutions.

5. Assemble an even more heterogeneous faculty.

As noted by ABET, "The faculty is the heart of any education program." The MLCE program faculty are very diverse in terms of areas of experience and their home institutions and countries. That diversity enriches the student experience.

Outside speakers and adjunct faculty are an integral part of some U.S. undergraduate and graduate civil engineering programs. Informed by the MLCE program, utilization of outside faculty might be taken to an even higher level.

\section{Concluding Comments}

Spain's five-year civil engineering programs devote very little time to group and personal management and leadership behaviour and to innovation. As described in this paper, that need prompted the development of an intense, short Master of Leadership in Civil Engineering (MLCE) program supported by a private foundation, organized and is operated by and at one of Spain's youngest civil engineering schools, and involving collaboration with the country's other nine civil engineering schools.

While this evolving program meets a need in Spain, elements of it may be of interest to members of the engineering profession in other countries who are designing master's programs or seeking ways to improve existing programs. Examples of potentially applicable elements are: 1) adopting the management-leadership-innovation theme of the MLCE program, 2) drawing on some of the content of the program, 3) incorporating a similar internship, 4) selecting top students from within a consortium of institutions to participate in a common program at one institution, and 5) assembling an even more heterogeneous faculty.

Because this is an evolving program, leaders of the MLCE program are considering options for further improvements. Accordingly, ideas from readers of this paper will be most welcome. 


\section{Appendix A: Example Spanish Undergraduate Civil Engineering Curriculum - University of Castilla-La Mancha, Ciudad Real, Spain}

\begin{tabular}{|c|c|c|}
\hline Year & Semester & Course \\
\hline \multirow[t]{2}{*}{1} & 1 & $\begin{array}{l}\text { Physics for Engineers } \\
\text { Mathematical Instruments for Engineering I } \\
\text { Computer Science } \\
\text { Drawing and Cartography } \\
\text { Geology }\end{array}$ \\
\hline & 2 & $\begin{array}{l}\text { Physics for Engineers } \\
\text { Statistics } \\
\text { Geometry } \\
\text { Ecology } \\
\text { Science and Technology of Materials }\end{array}$ \\
\hline \multirow[t]{2}{*}{2} & 1 & $\begin{array}{l}\text { Project Work: Roads } \\
\text { Mathematical Instruments for Engineering II } \\
\text { Differential Equations } \\
\text { Theory of Structures } \\
\text { Geomorphology }\end{array}$ \\
\hline & 2 & $\begin{array}{l}\text { Mechanics } \\
\text { Transport and Spatial Planning } \\
\text { Economy } \\
\text { Hydraulics and Hydrology } \\
\text { Elective Subjects }\end{array}$ \\
\hline \multirow[t]{2}{*}{3} & 1 & $\begin{array}{l}\text { Project Work: Urban and Regional Development } \\
\text { Mechanics of the Continuous Means and Material Science } \\
\text { City and Regional Planning } \\
\text { Hydrology and Fluvial Hydraulics }\end{array}$ \\
\hline & 2 & $\begin{array}{l}\text { Project Work: Transportation } \\
\text { Management and Infrastructures } \\
\text { Soil Mechanics } \\
\text { Road Layout and Traffic } \\
\text { Technology of Structures and Building I } \\
\text { Elective Subjects (Technical) }\end{array}$ \\
\hline \multirow[t]{2}{*}{4} & 1 & $\begin{array}{l}\text { Project Work: Building or Bridge } \\
\text { Technology of Structures and Building II } \\
\text { Transport Infrastructures }\end{array}$ \\
\hline & 2 & $\begin{array}{l}\text { Numerical Methods } \\
\text { Project Work: Fluvial and Water Planning } \\
\text { Hydraulic and Energy Engineering } \\
\text { Environmental Technologies } \\
\text { Project and Building Management } \\
\text { Non-major Subjects (mostly technical) }\end{array}$ \\
\hline
\end{tabular}




\begin{tabular}{|l|l|l|}
\hline 5 & 1 & $\begin{array}{l}\text { Business Administration } \\
\text { Landscape and Environmental Analysis } \\
\text { Public Works Management and Conservation } \\
\text { Maritime and Coastal Engineering }\end{array}$ \\
\cline { 2 - 3 } & 2 & $\begin{array}{l}\text { Final Dissertation } \\
\text { Elective Subjects (technical) } \\
\text { Non-major Subjects (mostly technical) }\end{array}$ \\
\hline
\end{tabular}




\section{Appendix B: Example Portion of the Leadership in Civil Engineering Program}

Title of Portion: Project Management and Related Communication

Class Time: Four hours per day for four days

Background and Objectives (excerpts): Presented here are the principles of project management as they could be applied throughout the life of civil engineering projects, that is, from concept through construction and into operations. The young civil engineer is introduced to a range of project management functions. Assignments given to students will provide an opportunity to apply project managing knowledge, skills, and attitudes (KSAs). Communication is important in managing and in leading, within and outside of projects. Accordingly, a portion of each day will be devoted to communication

Note: Numbers and text in parentheses are examples of target levels of cognitive achievement using Bloom's Taxonomy. See Appendix F in the ASCE report Civil Engineering Body of

Knowledge for the $21^{\text {st }}$ Century ${ }^{3}$ for a discussion of this taxonomy.

\begin{tabular}{|c|c|c|}
\hline Day & Topic & Student Work ${ }^{\mathrm{a}, \mathrm{b}}$ \\
\hline 1 & $\begin{array}{l}\text { Introduction: Purpose and Logistics } \\
\text { Leading, Managing \& Producing- } \\
\text { Different and Complementary (4: } \\
\text { Distinguish among the three } \\
\text { functions) } \\
\text { Characteristics of Successful Project } \\
\text { Managers } \\
\text { Communication-Writing: } \\
\text { Producing Action-Oriented } \\
\text { Documents (5: Integrate technical and } \\
\text { non-technical factors) }\end{array}$ & $\begin{array}{l}\text { - } \\
\text { - } \\
\text { - } \\
\text { Form teams } \\
\text { sescribe team project, create } \\
\text { symbol/icon, describe audience, } \\
\text { state principal message }\end{array}$ \\
\hline 2 & $\begin{array}{l}\text { Project Plans: Every Project Is } \\
\text { Done Twice (2: Explain two ways }\end{array}$ & $\begin{array}{l}\text { - Prepare network diagram for } \\
\text { project } \\
\text { - }\end{array}$ \\
\hline
\end{tabular}




\begin{tabular}{|c|c|c|}
\hline & $\begin{array}{l}\text { of doing a project twice. } 4 \text { : Analyze } \\
\text { risks and their probabilities) } \\
\text { Communication-Speaking: } \\
\text { Making Things Happen ( } 5 \text { : } \\
\text { Collaborate to create a message and } \\
\text { the means to deliver it) }\end{array}$ & \\
\hline 3 & $\begin{array}{l}\text { Quality: What Is It? How Do We } \\
\text { Achieve It? (3:Show the importance } \\
\text { of team-wide understanding of } \\
\text { quality) } \\
\text { Communication-Within and } \\
\text { Outside of the Project Team }\end{array}$ & $\begin{array}{ll}\text { - } & \text { Brainstorming } \\
\text { - } & \text { Multivoting }\end{array}$ \\
\hline 4 & $\begin{array}{l}\text { Marketing Professional Services: } \\
\text { Introduction (3. Explain the } \\
\text { importance of mutual trust) } \\
\text { Resume Tips: Emphasis on } \\
\text { Managing and Leading } \\
\text { Scope Creep: Preventing \& } \\
\text { Resolving Examination }\end{array}$ & \\
\hline
\end{tabular}

a) In and/or out of class

b) Readings are assigned from these books and the books are available in the students'

Residence hall: Engineering Your Future: The Non-Technical Side of Professional Practice in Engineering and Other Technical Fields, ASCE Press, 2000, and Managing and Leading:

52 Lessons Learned for Engineers, ASCE Press, 2004, both authored by S. G. Walesh

c) Assigned prior to and used on the first day. 


\section{Appendix C: Books Used For Reading Assignments}

Aronson, E. The Social Animal, New York, NY: Worth/Freeman, 2008

Caplow, T. Two Against One: Coalitions in Triads, Englewood Cliffs, NJ: Prentice Hall, 1968.

Covey, S. R. The 7 Habits of Highly-Effective People, New York, NY: Simon \& Schuster, 1990.

Font, A, Negociar Con Arte, Spain: Alienta, 2008.

Goleman, D., R. Boyatzis, and A. McKee. Primal Leadership: Learning to Lead With Emotional Intelligence, Cambridge, MA: Harvard Business School Press, 2002.

Kotter, J. P. Leading Change, Cambridge, MA: Harvard Business School Press, 1996.

McKee, A., R. Boyatzis, and F. Johnston. Becoming a Resonant Leader: Develop Your

Emotional Intelligence, Renew Your Relationships, Sustain Your Effectiveness, Cambridge, MA: Harvard Business School Press, 2008.

Sutherland, S. Irrationality: The Enemy Within, London, UK: Pinter \& Martin, 2007.

Walesh, S. G. Engineering Your Future: The Non-Technical Side of Professional Practice in Engineering and Other Technical Fields, Reston, VA: ASCE Press, 2000.

Walesh, S. G. Managing and Leading: 52 Lessons Learned for Engineers, Reston, VA: ASCE Press, 2004.

Watzlawick, P. The Situation Is Hopeless But Not Serious: The Pursuit of Unhappiness, New York, NY: Norton, 1983. 


\section{Appendix D: Faculty and Leaders Who Participated in the 2009 Edition of the MLCE Program}

\begin{tabular}{|c|c|c|c|c|}
\hline FACULTY \& LEADERS & DEGREES & CURRENT POSITION & INSTITUTION & COUNTRY \\
\hline Javier Conde & $\begin{array}{l}\text { Ph.D. Mechanical } \\
\text { Engineer }\end{array}$ & Full Professor & UNED & SPAIN \\
\hline Stuart G. Walesh & Ph.D.P.E. & $\begin{array}{l}\text { Consultant, author, and } \\
\text { Professor Emeritus }\end{array}$ & S.G. Walesh Consulting & U.S. \\
\hline Enrique Viaña & Ph. D. B.S. Economics & Full Professor & UCLM & SPAIN \\
\hline Jose $M^{\mathrm{a}}$ Menéndez & Ph.D. Civil Engineer & Full Professor & UCLM & SPAIN \\
\hline J.R.Páramo & Ph. D. B.S. Law & Full Professor & UCLM & SPAIN \\
\hline Raul Calvo & Ph. D. B. S. Philosophy & $\begin{array}{l}\text { Full Professor Judicial } \\
\text { and Social Science }\end{array}$ & Girona University & SPAIN \\
\hline Alfred Font & Ph. D. B.S. Law & $\begin{array}{l}\text { Lawyer, Teacher } \\
\text { of negotiation }\end{array}$ & Pompeu Fabra University & SPAIN \\
\hline Jose Mª Ureña & Ph.D. Civil Engineer & Full Professor & UCLM & SPAIN \\
\hline Anna Castells & Ph. D. Journalism & $\begin{array}{l}\text { Independent consultant } \\
\text { and journalist }\end{array}$ & Communication Consulting & SPAIN \\
\hline Antonio Linares & Ph.D. Civil Engineer & $\begin{array}{l}\text { Organizational } \\
\text { researcher and } \\
\text { consultant }\end{array}$ & U.A.M. AULATIKA MADRID & SPAIN \\
\hline Gonzalo Ruiz López & Ph.D. Civil Engineer & Full Professor & UCLM & SPAIN \\
\hline Isabel Cuadrado & Ph.D. Psychology & Full Professor & UNED & SPAIN \\
\hline Gloria de la Torre & Degree in Psychology, & $\begin{array}{l}\text { Director of Human } \\
\text { Resources }\end{array}$ & AERTEC & SPAIN \\
\hline Paul Lambert & Ph.D.P.I. A. E... & Professor of Marketing & Ecole Hoteliere de Lausane & SWITZERLAND \\
\hline Daniel Maguire & Ph.D.P.E & Vice Chairman & Executive Construction Inc & U.S. \\
\hline Jill Andrei & Ph.D.P.E. & Managing Director & Motis Coaching & HOLLAND \\
\hline Jaime del Barrio & Ph.D. Civil Engineer & Managing Director & ROCHE & SPAIN \\
\hline $\begin{array}{l}\text { L. Javier Conde } \\
\text { Londoño }\end{array}$ & Economist & Managing Director & EMT & SPAIN \\
\hline $\begin{array}{l}\text { Antonio Gómez- } \\
\text { Guillamón }\end{array}$ & Aeronautical Engineer & Director & AERTEC & SPAIN \\
\hline . Casimiro Iglesias & Civil Engineer & $\begin{array}{l}\text { Director General of } \\
\text { Territorial Planning }\end{array}$ & Ministry of Development & SPAIN \\
\hline Antonio Monfort Bernat & Civil Engineer & Director & INECO TIFSA & SPAIN \\
\hline
\end{tabular}

Note: The last five are leaders, that is, executives who shared experiences with the students. 


\section{Bibliography}

1. Covey, S. R. The 7 Habits of Highly-Effective People, New York, NY: Simon \& Schuster, 1990.

2. Foundation Rafael Del Pino. "Annual Report 2008."

(http://www.frdelpino.es/documentos/AnnualReport2008_Fundaci\%C3\%B3nRafaeldelPino.pdf)

3. ASCE Body of Knowledge Committee. Civil Engineering Body of Knowledge for the $21^{\text {st }}$ Century: Preparing the Civil Engineer for the Future-Second Edition, Reston, VA; ASCE, 2008.

4. National Academy of Engineering. Educating the Engineer of 2020: Adapting Education to the New Century, Washington, DC: National Academy of Engineering of the National Academies, 2005.

5. National Society of Professional Engineers. "Professional Policy No. 168 - Engineering Education Requirements," Alexandria, VA: NSPE, 2002.

6. National Council of Examiners for Engineering and Surveying. Model Law, Clemson, NC: August, 2007.

7. American Academy of Environmental Engineers. Environmental Engineering Body of Knowledge, Annapolis, MD, 2009.

8. Armstrong, R. C. "A Vision of the Chemical Engineering Curriculum of the Future," Chemical Engineering Education, Vol. 40, No. 2, pp. 104-109, 2006.

9. "Imagining 2028: Mechanical Engineering Leaders Create A Vision for the Future and Specify the Challenges in the Coming Years," PE, NSPE, p. 6, October 2008. Go to www.asmeconferences.org/asmeglobalsummit for the report 2028 Vision for Mechanical Engineering. 